Vol. 44, N. 3 : pp. $223-225$, September, 2001 ISSN 1516-8913 Printed in Brazil

\section{BRAZILIAN ARCHIVES OF BIOLOGY AND TECHNOLOGY}

\title{
Bioaccumulation of Silver and the Isolation of Metal- Binding Protein from P.diminuta
}

\author{
Zaharah Ibrahim*, Wan Azlina Ahmad and Abu Bakar Baba \\ Department of Chemistry, Faculty of Science, Universiti Teknologi Malaysia, 81310 Skudai, Johor, Malaysia
}

\begin{abstract}
A silver uptake study by Pseudomonas diminuta was carried out by growing the bacteria in a chloride-free medium $(C F M)$ containing silver ions $(50 \mu M)$ in a batch culture. From the results, it was found that higher amounts of silver were accumulated inside the cell during early exponential phase compared to the amount bound at the cell surface. This suggested a possible mechanism for metal uptake during bacterial growth. In view of this, attempts were made to isolate proteins which might be associated with silver-binding properties from cultures of P.diminuta grown in the presence and absence of silver. The proteins were first extracted from the bacterial cultures by precipitation with ammonium sulfate followed by purification using isoelectric focussing and SDS-PAGE. Results of the experiment showed the presence of low molecular weight and high molecular weight proteins containing silver with pI values ranging from 2.0 to 9.0 for bacteria grown in the presence of silver.
\end{abstract}

Key words: Bioaccumulation, metal-binding proteins, Pseudomonas diminuta

\section{INTRODUCTION}

Microorganisms have evolved several mechanisms that respond to the toxic effects of heavy metals. One of the common mechanisms is the induction of metal binding proteins following the uptake of metals into the cells. A well-studied class of metal binding proteins is called metallothioneins (MTs) or low molecular weight cysteine-rich proteins. A unique property of this class of proteins is their inducibility in response to heavy metals (Gadd, 1988). Metallothioneins have been isolated from diverse organisms including mammals, yeast, algae and fungi. Their presence have been implicated in metal homeostasis and detoxification (Butt and Ecker, 1987).

The isolation of bacterial cadmium proteins from P. putida and cystine-rich protein from P. cepacia grown in $\mathrm{Au}(\mathrm{I})$ thiolate may have a common role in detoxification (Higham and Sadler, 1984).

This paper reports the accumulation of silver by growing cells of P.diminuta and the purification of silver binding protein.

\section{MATERIALS AND METHODS}

Microorganism and culture conditions

$P$. diminuta, a gram-negative bacteria, previously isolated from a mining environment in Malaysia was used throughout the study (Ibrahim, 1993). The chloride-free medium (CFM) was used to minimize the precipitation and complexation of $\mathrm{Ag}^{+}$with the medium components (Ahmad, 1993). $P$. diminuta was grown in CFM supplemented with $50 \mathrm{uM} \mathrm{Ag}^{+}$. The cultures were incubated at $30^{\circ} \mathrm{C}$ and grown to stationary phase in 2-litre flask at $200 \mathrm{rpm}$. Cells were harvested by centrifugation at $10000 \mathrm{rpm}$ at $4^{\circ} \mathrm{C}$. The supernatant and cell pellet were treated separately for the extraction of proteins. Similarly, as a control, $P$. diminuta was grown in the absence of silver.

\section{Silver uptake experiment}

The uptake of silver by $P$. diminuta grown in the presence of silver was carried by growing the bacteria in $100 \mathrm{ml}$ CFM containing $50 \mathrm{M} \mathrm{Ag}^{+}$ incubated at $200 \mathrm{rpm}, 30^{\circ} \mathrm{C}$ until the stationary phase. Aliquots of the sample were taken out at some regular time intervals for the determination of its dry weight and silver content. The samples

\footnotetext{
*Author for correspondence
} 
were centrifuged and resuspended in PIPES buffer before the supernatant, washings and cell digests were analysed for their silver content using the atomic absorption spectrometer (Ibrahim, 1993).

\section{Protein extraction and purification}

For the cultures grown in the presence of $\mathrm{Ag}^{+}$, the cell pellet was separated from its supernatant by centrifugation. The pellet was lysed with lysozyme (10 $\mathrm{mgml}^{-1}$ in $0.25 \mathrm{M}$ Tris, $\mathrm{pH} \mathrm{8.0)}$ and liquid nitrogen was added to facilitate grinding of the cells. The liquid fraction was separated from the cell debris by centrifugation at $10000 \mathrm{rpm}$ at $4^{\circ} \mathrm{C}$. The protein was extracted from the supernatant by adding solid ammonium sulphate and precipitated proteins were collected by centrifugation at 15000 $\mathrm{rpm}$ at $4^{\circ} \mathrm{C}$. Similar procedure was followed for the extraction of proteins from the supernatant and that of the control. The proteins were purified using the Rotorfor Preparative Isoelectric Focussing (IEF) Cell (BioRad, Inc, USA). The protein extract and ampholytes with $\mathrm{pI}$ values ranging from 3 to 10 , was added to the sample. The sample was loaded into the rotorfor cell and was electrophoresesed at a constant power of 12 Watts for 3 to $4 \mathrm{hrs}$. Selected fractions were further analysed using the SDS-PAGE.

For the SDS-PAGE, solutions were prepared according to the procedure: given by Deutscher (1990). The fractions were analysed using the disc electrophoresis. Prior to electrophoresis, equal volume of the protein sample $(10 \mathrm{uL})$ was added to the sample buffer comprising of Tris- $\mathrm{Cl} \mathrm{pH} 6.8$, glycerol $(0.5 \mathrm{M})$, SDS $10 \%$ and bromophenol blue $(0.05 \% ; \mathrm{w} / \mathrm{v})$ and heated at $95^{\circ} \mathrm{C}$ for $4 \mathrm{~min}$. The sample was loaded into the wells of the stacking gel together with pre-stained SDS-PAGE standard (Bio-Rad). The electrophoresis was run at a constant voltage of $150 \mathrm{~V}$ for $30 \mathrm{~min}$ (Ibrahim, 1993).

\section{RESULTS AND DISCUSSION}

\section{Silver uptake experiment}

The accumulation of silver at the cell surface (acid washing) and intracellularly (pellet digestion) by $P$. diminuta grown in the presence of $50 \mathrm{M} \mathrm{Ag}^{+}$is shown graphically in Fig. 1 below.

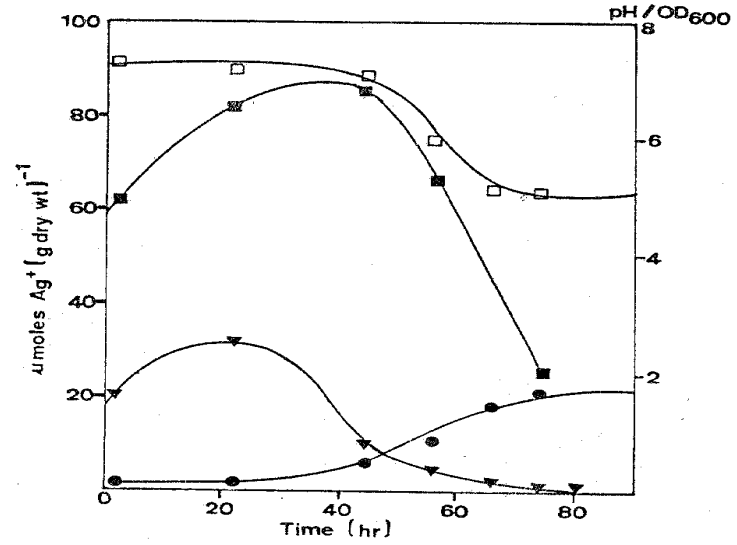

Figure 1- Binding of cells grown in $50 \mu \mathrm{M} \mathrm{Ag}^{+}$ $(\boldsymbol{\nabla})$ acid washing ( $\mathbf{a})$ pellet digest (口) $\mathrm{pH}$

(•) $\mathrm{OD}_{600}$

From the results, it was found that silver accumulation by acid washing was maximum during the lag phase and early exponential growth period. This corresponds to $32 \mu$ moles (g dry wt) ${ }^{-1}$ $\mathrm{Ag}^{+}$bound at the cell surface of the bacteria during 15-22 $\mathrm{h}$ of its incubation period. This was followed by a decrease in the metal accumulated during mid-exponential and stationary phase of growth. Concurrently, there was also a rapid decrease of $\mathrm{pH}$ of the cultures during the early exponential phase and $\mathrm{pH}$ continue to drop to as low as 5.11 during stationary phase. This may probably due to a shift of the bacterial metabolism towards less efficient, fermentative growth, leading to an increase in organic acid formation. As for the intracellularly-bound silver (pellet digestion), generally the amount of silver accumulated inside the cell is much greater than that at the cell surface (Thomas, 2000). The maximum amount of the metal accumulated during $35-40 \mathrm{~h}$ of incubation (early exponential) is about $88 \mu$ moles $\mathrm{Ag}^{+}$(g dry wt) ${ }^{-1}$. This may be attributed to additional aspects of metabolism of internal detoxification that allows complexation and precipitation of the metal during growth of the bacteria (Gadd, 1988).

To determine if enhanced accumulation of the metal inside the cell may be related to the synthesis of proteins, attempts were made to extract proteins from cultures of bacteria grown in the presence of silver. Bacterial proteins were extracted from the cells and the supernatant by ammonium sulfate precipitation and were further purified based on isoelectric focussing. Selected fractions which absorbed strongly at $260 \mathrm{~nm}$ and $280 \mathrm{~nm}$ were analysed using the SDS-PAGE. Results of the SDS-PAGE of protein extracted from the supernatant of cells grown in silver 
showed the presence of low molecular weight proteins ranging from 10000 to 12500 (Fig. 2). Protein extracted intracellularly were of high molecular weight, ranging from 20000 to 141000 . The $\mathrm{pI}$ values also differed that is 1.7 to 2.0 for the extracellular extract compared to 8.0 to 8.9 for intracellular protein. These fractions were also found to contain $\mathrm{Ag}^{+}$, up to $20 \mathrm{uM}$ upon analysis with atomic absorption spectrometer.

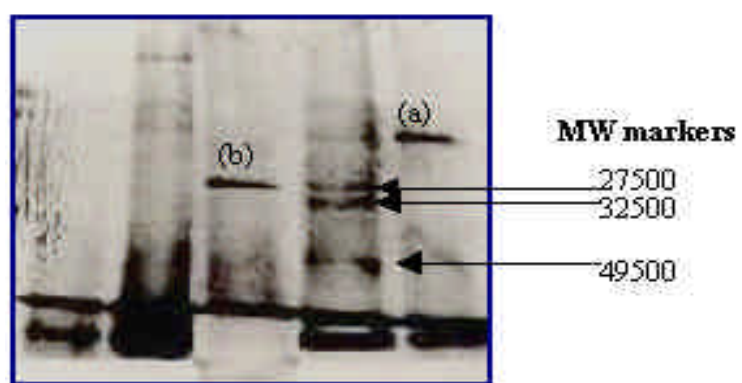

Figure 2 - (a) Protein extract of supernatant of bacteria grown in $50 \mu \mathrm{M} \mathrm{Ag}^{+}$; (b) Protein extract of supernatant of bacteria grown in the absence of $\mathrm{Ag}^{+}$(Control).

In conclusion, from the experiments that has been carried out, there were at least 2 types of proteins which might have a common role of binding to silver ions. These proteins may possibly function to detoxify $\mathrm{Ag}^{+}$, thus allowing the organisms to survive. It should also be noted that the proteins extracted from the supernatant (growth medium) and the cell pellet in the absence of silver did not show the presence of silver-containing proteins. Future work in this area will include amino-acid analysis, circular dichroism and optical rotary dispersion. This will further aid in protein characterization and if there is any resemblance to metallothionein, whose function is well understood.

\section{ACKNOWLEDGEMENTS}

The authors would like to thank the Ministry of Science, Technology and the environment for financial support and the Research Management Centre, Universiti Teknologi Malaysia.

\section{RESUMO}

Um estudo sobre o crescimento de Pseudomonas diminuta em um meio contendo cloreto livre (CFM) e íons de prata na concentração $(50 \mu \mathrm{M})$ em uma cultura em batelada. Os resultados demonstraram que grandes quantidades de prata foram acumuladas dentro da célula durante a fase exponencial de crescimento comparada à uma quantidade limitada na superfície da célula. Isto sugeriu um mecanismo captação do metal durante o crescimento bacteriano. Em vista disto, tentativas foram realizadas no sentido de isolar as proteínas relacionadas com a propriedade de se ligar a prata em cultura P.diminuta em um meio contendo ou não íons prata. As proteínas foram extraídas das culturas bacterianas pela precipitação com o sulfato do amônio seguido de sua purificação utilizando um focalizador isoelétrico e SDS-PAGE. Os resultados desta experiência mostraram a presença de proteínas de alto e baixo peso molecular contendo prata com pI variando entre 2,0 a 9,0 quando as bactérias crescem na presença da prata.

\section{REFERENCES}

Ahmad, W. A. (1988), "Characterisation of Metal Resistant Bacteria from a Mining Environment". Ph.D. Thesis, University London, London, England

Butt, T. R. and Ecker, D. J. (1987), Microbiological Reviews 51, 3, 351-364

Gadd, G. M. (1988), "Special Processes" Biotechnology, Weinheim, R. Ed.: VCH Verlagsgesellschaft, 401-433

Higham, D. P. and Sadler, P. J. (1984), Science, 225; 1043-1045

Ibrahim, Z. (1993), "Characterisation of Silver Resistant Bacteria from a Mining Environment". Ph.D. Thesis, Universiti Teknologi Malaysia, Skudai, Malaysia

Thomas, R. A. (2000), "Uptake of Silver of $\underline{P \text {. diminuta }}$ in Simulated Effluent". B.Sc. Thesis, Universiti Teknologi Malaysia, Skudai, Malaysia 